\title{
Physical activity of children and adolescents from the Czech Republic, Hungary, Poland, and Slovakia: A systematic review
}

\author{
Adam Kantanista ${ }^{1, A-F \oplus}{ }^{\oplus}$ Jacek Tarnas ${ }^{1, B-F}{ }^{\oplus}$, Joanna Borowiec ${ }^{1, B, D-F}{ }^{\oplus}$, Helena Elegańczyk-Kot ${ }^{1, B, E-F}{ }^{\oplus}$, \\ Adrian Lubowiecki-Vikuk ${ }^{2, C-F}{ }^{\text {, }}$ Mikołaj Marciniak ${ }^{1, C, E-F \oplus}$, Magdalena Król-Zielińska ${ }^{1, B-F \oplus}$ \\ ${ }^{1}$ Poznan University of Physical Education, Poznań, Poland \\ 2 SGH Warsaw School of Economics, Warsaw, Poland \\ A - Research concept and design, B - Collection and/or assembly of data, C - Data analysis and interpretation, \\ $D$ - Writing the article, E - Critical revision of the article, F - Final approval of article
}

Kantanista A, Tarnas J, Borowiec J, Elegańczyk-Kot H, Lubowiecki-Vikuk A, Marciniak M, Król-Zielińska M. Physical activity of children and adolescents from the Czech Republic, Hungary, Poland, and Slovakia: A systematic review. Ann Agric Environ Med. $2021 ; 28(3)$ : 385-390. doi: $10.26444 /$ aaem/125557

\begin{abstract}
Introduction and objective. Systematic monitoring of physical activity of young populations from different regions may be useful for making international comparisons, better understanding trends in physical activity and designing public health interventions to increase physical activity. Thus, the aim of the study was to comprehensively review studies examining the level of physical activity of children and adolescents from the Visegrád countries, and indicate the percentage of children and adolescents meeting the recommended level of physical activity.

Materials and method. A systematic search of the published literature was conducted. Included were reports with original research that consisted of the proportion of children and adolescents who met physical activity recommendations or guidelines. To provide a current picture of physical activity of children and adolescents, the review was restricted to studies published between January 2015 - November 2018.

Results. Moderate-to-vigorous physical activity recommendations were met by between $7.5 \%-69.4 \%$ of children and adolescents. Vigorous physical activity recommendations were met by between $33.6 \%-64.5 \%$ of children and adolescents. Daily recommendations for the number of steps taken were fulfilled by between $11.6 \%-69.0 \%$ of children and adolescents. Differences between age categories, genders and countries were observed.

Conclusions. Public health interventions to increase physical activity are required to decrease insufficient levels of physical activity in children and adolescents, especially in girls. The review also highlights the need for studies with representative random samples that use validated measurement methods.
\end{abstract}

\section{Key words}

health, exercise, recommendations, Visegrád

\section{INTRODUCTION}

The health benefits of being physically active are broadly recognised. For children and adolescents, physical activity at the appropriate level improves the cardiovascular system and the quality of bones, in addition to aiding weight management and reducing symptoms of depression $[1,2$, 3]. Physical inactivity leads to energy imbalance and can increase the risk of becoming overweight or obese $[4,5]$ and developing factors in cardiovascular diseases, such as high blood pressure, insulin resistance and glucose intolerance [1].

The World Health Organization (WHO) [6] recommends that children and adolescents aged 5-17 should perform at least 60 minutes of moderate-to-vigorous intensity physical activity (MVPA) daily. However, globally, over $80 \%$ of those aged 11-17 do not comply with physical activity recommendations [7]. In addition, the results of the Health Behaviour in School-aged Children (HBSC) survey showed that, in Europe, only $23.1 \%$ of boys and $14.0 \%$ of girls aged 13-15 years met the WHO recommendations for daily physical activity [8]. Vigorous physical activity (VPA) may

Address for correspondence: Adam Kantasista, Poznan University of Physical Education, Królowej Jadwigi 27/39, 61-871, Poznań, Poland

E-mail: adam.kantanista@gmail.com

Received: 27.03.2020; accepted: 20.07.2020; first published: 05.08.2020 be especially beneficial for children and youths [9]. Based on a review of studies, Owens et al. [10] concluded that higher levels of VPA among youths were associated with improved blood lipid profiles, were beneficial for blood pressure, increased the aerobic capacity of youths, and improved body composition. The WHO [5] recommends that children and adolescents should participate in vigorous-intensity activities at least 3 times per week. Unfortunately, it appears that a too small percentage of children and adolescents engage in VPA on a daily basis $[11,12]$.

The time children and adolescents spend watching television or using electronic media has resulted in more sedentary time and less physical activity. According to the WHO European Childhood Obesity Surveillance [13], which studied 18 countries, $22 \%-52 \%$ of children spend at least 2 hours every weekday watching television programmes or using electronic media; on weekend days, the figure ranges from $52 \%-91 \%$. Children's sedentary habits may be maintained through to adolescence and adulthood. This is concerning because physical inactivity is among four risk factors - along with hypertension, smoking, and high glucose levels - associated with premature morbidity worldwide [14].

Poland, the Czech Republic, Slovakia, and Hungary form an alliance of four Central European states called the Visegrád Group. These countries share historical and political 
roots and monitored indicators (e.g. health standards) in these countries may develop similarly [15]. In the Visegrád countries, the percentage of gross domestic product (\% GDP) for health ranges from 4.6 in Poland to 7.4 in the Czech Republic and Slovakia; \% GDP for education ranges from 3.8 in Slovakia to 5.0 in Poland; and the \%GDP for sport ranges from 0.2 in Slovakia to 1.1 in Hungary [16].

Despite low indicators in selected sectors of the national economies of the Visegrád countries, the levels of physical activity of the young generation are higher than in most Asian, African and Latin American countries, but lower than youth from countries such as Ireland, the USA, Greenland and Bangladesh [7]. The physical activity levels of children and adolescents may be improved by participation in organized forms of physical activity [17], including physical education lessons. According to the WHO [16], students participate in a different number of mandatory physical education classes per week: in Poland - 3-4 hours, in the Czech Republic - 2 hours, in Slovakia - 3 hours, and in Hungary - 5 hours. Additionally, in the Czech Republic, many schools have voluntarily included 1-4 extra hours of physical activity per week. Thus, the education systems in the Visegrád countries offer opportunities for physical activity for children and adolescents.

\section{OBJECTIVES}

Monitoring the physical activity of the younger population in developing socio-economic environments, taking into account relevant factors $[18,19]$, may help make international comparisons, better understand physical activity trends and design public health intervention to increase physical activity. Thus, the aim of the study is to comprehensively review studies examining the levels of physical activity of children and adolescents in the Visegrád countries, and indicate the percentage of children and adolescents meeting the recommended level of physical activity.

\section{MATERIALS AND METHOD}

Search strategy. The comparative literature analysis method adopted by the authors is often used in the research of physical activity in children and adolescents [20, 21, 22]. The guidelines followed were those outlined as the preferred reporting items for systematic reviews to ensure transparent reporting [23]. The literature analysed was identified by searching electronic databases.

Electronic searches of computerised databases were performed according to a protocol agreed to by all co-authors. Four databases were searched: SportDiscus with Full Text, MEDLINE and Health Source: Nursing/Academic Edition via EBSCO, SCOPUS and Web of Science. A literature search for papers was carried out using keyword combinations (Tab. 1). If an abstract was not available, the first 1,500 characters of the HTML full text of the article were searched. On the Web of Science database, topic and title field were used. The search was conducted on 25 November 2018.

Papers were reviewed if they met the following criteria: original research published in English; no book chapters or conference proceedings; physical activity was reported for children and adolescents aged 5-18 years; the sample included
Table 1. Search terms used for study identification

\begin{tabular}{ll}
\hline Facets & Search terms \\
\hline Physical activity & $\begin{array}{l}\text { Exercise OR exercises OR physical activity OR physical } \\
\text { activities }\end{array}$ \\
\hline Children/adolescents & $\begin{array}{l}\text { Child OR children OR adolescent OR adolescents OR } \\
\text { teenager OR teenagers OR youth }\end{array}$ \\
\hline Countries & $\begin{array}{l}\text { Poland OR Polish OR Czech Republic OR Czech OR } \\
\text { Hungary OR Hungarian OR Slovakia OR Slovak }\end{array}$ \\
\hline
\end{tabular}

healthy populations from some combination of Poland, the Czech Republic, Slovakia, and Hungary; published between January 2015 - November 2018. Papers were excluded from the review if the results included subjects under 5-years-old (e.g. 3-10-years-old) or subjects above the age of 18 years (e.g. 15-20-years-old) without division into the age categories pertaining to this study. Neither unpublished studies nor 'grey' literature was analysed. The literature identification process is shown in Fig. 1.

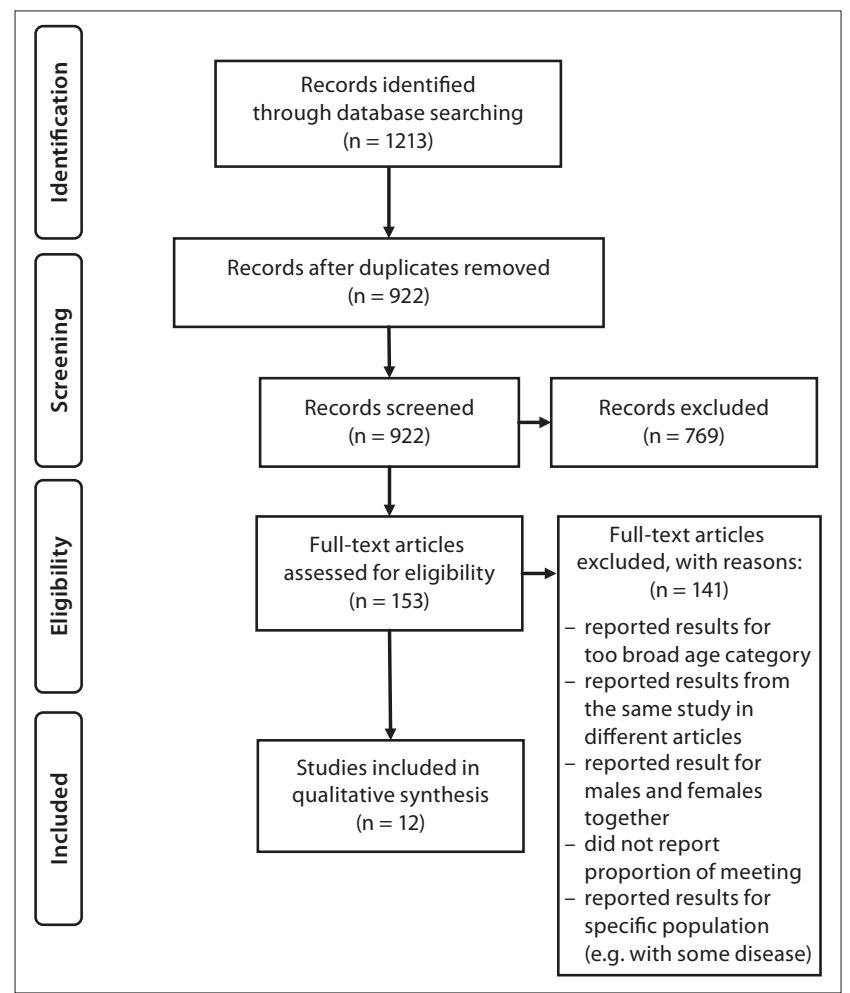

Figure 1. Flow diagram for the identification, screening, eligibility, and inclusion of studies

Data extraction. The search was conducted by a library curator with systematic-review expertise. Articles were extracted and imported into EndNote software. Duplicate articles were removed using Endnote. The titles and abstracts of potentially relevant articles were analysed by two reviewers (AK and JT). The full texts of papers passing initial screening were then obtained. Then MK-Z with JB and MM with HE-K analysed full texts of copies of the papers independently. If an article was included by one reviewer and not the other, the article was sent to a third reviewer for further review. From the initial list, the following elements were extracted and recorded: author(s) and year of publication; participants (sample size, gender, age and country); measurement method; criteria for physical activity recommendations; and 
percentage of sufficient active subjects. Extracted information was discussed and papers presenting the same research results were excluded, resulting in the final selection of papers.

\section{RESULTS}

A total of 12 articles were included in the analysis (Tab. 2). The articles contained the results of six studies from the Czech Republic $(\mathrm{n}=22,237)$, five from Poland $(\mathrm{n}=2,474)$ and one each from Hungary $(\mathrm{n}=975)$ and Slovakia $(\mathrm{n}=8,042)$. In total, 33,728 children and adolescents were studied ( 8 of the 12 studies included representative research samples). The analysed studies were carried out in various years, sometimes at the turn of two years. In some studies, there is no information on the year of the research. Therefore, it was not possible to determine what percentage of the surveyed children and adolescents constitute the population of each country.

Most research was carried out during an HBSC study which provided information about the health, well-being, social environment and health behaviour of 11-, 13- and 15 -year-old boys and girls. In the presented review, physical activity in HBSC studies was measured by an item asking adolescents about the number of days over the past week that they were physically active for a total of at least $60 \mathrm{~min}$ per day.

\section{Meeting physical activity recommendations.} Recommendations for MVPA were met by $7.5 \%-69.4 \%$ and for VPA by $33.6 \%-64.5 \%$ of children and adolescents. The daily recommendation of 12,000 steps was met by $11.6 \%$ $-69.0 \%$ of children and adolescents, while $39.8 \%$ to $53.3 \%$ completed 11,500 steps per day.

Gender differences in physical activity. Recommendations for MVPA were met by $14.6 \%-40.5 \%$ of boys and $7.5 \%$ $-25.2 \%$ of girls. The VPA recommendations were met by $39.4 \%-64.5 \%$ of boys and $30.2 \%-51.3 \%$ of girls. The daily recommendation of 12,000 steps was met by $69.0 \%$ of boys and $11.6 \%-51.4 \%$ of girls, while $50.5 \%-53.3 \%$ of boys and $39.8 \%-48.3 \%$ of girls completed 11,500 steps per day.

Physical activity across age groups. The daily recommendation of 11,500 steps was met by $39.8 \%-53.3 \%$ of children aged $5-7$, while $51.4 \%-69.0 \%$ completed 12,000 steps per day. Recommendations for MVPA were met by $8.0 \%$ $-29.5 \%$ of $7-12.49$-year-old children; $7.5 \%$ to $69.4 \%$ of those aged $12.5-18$ years fulfilled the criteria. Recommendations for VPA were achieved by $34.4 \%-39.4 \%$ of $10.5-12.49$-yearold children and $30.2 \%-64.5 \%$ of $12.5-16.49$-year-old adolescents.

Physical activity across countries. Recommendations for MVPA were met by $8.0 \%-32.3 \%$ of children and adolescents from the Czech Republic, 8.5\% - 14.6\% of adolescents from Hungary, $7.5 \%-69.4 \%$ of children and adolescents from Poland, and $25.1 \%$ of children and adolescents from Slovakia. Recommendations for VPA were met by $33.4 \%-45.9 \%$ of adolescents from the Czech Republic and 51.3\% - 64.5\% of adolescents from Poland. The daily recommendation of 11,500 steps was met by $39.8 \%-53.3 \%$ of children from the Czech Republic; $11.6 \%-69.0 \%$ of children and adolescents from Poland completed 12.000 steps per day.

\section{DISCUSSION}

The review aimed to examine the levels of physical activity of children and adolescents from the Visegrád countries and indicate the percentage of children and adolescents meeting the recommended levels of physical activity. In the studies analysed, different percentages of respondents met the recommended level of physical activity. Recommendations of MVPA were met by $7.5 \%-69.4 \%$ of the total sample, VPA recommendations were met by $33.6 \%-64.5 \%$ of the total sample, and daily recommendations for the number of steps were met by $11.6 \%-69.0 \%$ of the total sample. The range of results obtained was very wide and caused difficulties for clearly estimating the levels of physical activity of children and adolescents. The selection of children and adolescents for research could have an impact on this. From among the 12 analysed articles, eight could be qualified as representative samples and only five as national representative samples. In the studies where the criterion of representativeness was not met, compared to studies with representative samples, there was a higher percentage of children and adolescents fulfilling the recommendation of physical activity. In addition, there continues to be an absence of research on this issue, particularly regarding children and adolescents from Hungary and Slovakia.

It turned out that a higher percentage of boys reached the recommended level of physical activity compared to girls. Guthold et al. [7] evaluated trends in insufficient physical activity among adolescents and showed that high percentages of girls completed insufficient physical activity in Hungary (85.8\%), Poland (84.2\%), the Czech Republic (82.0\%) and Slovakia (77.8\%). The authors of 10 out of 12 articles indicated that, in general, a twice as low percentage of girls than boys met the recommended MVPA. Tabak et al. [33] and Gába et al. [26] demonstrated even greater differences (7.5\% girls compared to $22.8 \%$ boys; $8.0 \%$ girls compared to $22.0 \%$ boys). As for the recommended VPA and the recommendations for the number of steps, although the gender differences were smaller, the percentages were still higher for boys. The lower levels of girls' physical activity corroborate the findings of earlier studies [7, 34]; furthermore, this result can be considered consistent with general research on the physical activity of girls [28].

Significant differences in the levels of physical activity for children and adolescents depending on their age category were observed. The results were consistent with other studies $[35,36]$ and indicated that the older the children, the lower the level of MVPA. This could be seen most clearly in the 14-18-year-old bracket, where the rate ranged from $7.5 \%$ $22.8 \%$. The recommended level of MVPA was observed in only one out of five adolescents aged 15 [27]. A study by Frömel et al. [11] contradicted this, and taking into account gender and country of origin, determined that the recommended level of MVPA was met by every fifth girl from the Czech Republic and every fourth girl from Poland. Considering the age of the children and adolescents, as in previous studies [37], the results of the papers analysed were not consistent in terms of the recommended level of physical activity. Moreover, they were not complete, as it was impossible to determine the actual level of physical activity undertaken by children aged 8-10-years-old. This may be related to the physical and motor development of children of this age, who show a significant need for physical activity during this period [38]. 
Table 2. Physical activity (PA) of children and adolescents from the Visegrád countries

\begin{tabular}{|c|c|c|c|c|}
\hline $\begin{array}{l}\text { Author(s), year } \\
\text { of publication }\end{array}$ & $\begin{array}{l}\text { Participants (sample size, } \\
\text { gender, age and country) }\end{array}$ & Measurement method & $\begin{array}{l}\text { Criteria for recommendation } \\
\text { of physical activity }\end{array}$ & $\%$ of sufficiently active subjects \\
\hline $\begin{array}{l}\text { Brindova et al. } \\
{[24]}\end{array}$ & $\begin{array}{l}8,042 \text { children and adolescents } \\
(3,910 \text { boys, } 4,132 \text { girls) } \\
\text { aged } 11-15, \\
\text { national representative sample } \\
\text { Slovakia }\end{array}$ & $\begin{array}{l}\text { HBSC study: self-reported MVPA, number } \\
\text { of days physically active at least } 60 \\
\text { minutes, last } 7 \text { days }\end{array}$ & $\begin{array}{l}\text { At least } 60 \text { minutes per day } \\
\text { of MVPA }\end{array}$ & $25.1 \%$ \\
\hline Czajka et al. [25] & $\begin{array}{l}221 \text { children } \\
\text { (116 boys, } 105 \text { girls) } \\
\text { aged } 6-7, \\
\text { regional sample } \\
\text { Poland }\end{array}$ & $\begin{array}{l}\text { HJ-113 pedometer (Omron, Japan), step } \\
\text { counts, } 7 \text { consecutive days }\end{array}$ & 12,000 steps per day & $69.0 \%$ boys, $51.4 \%$ girls \\
\hline $\begin{array}{l}\text { Frömel et al. } \\
{[11]}\end{array}$ & $\begin{array}{l}1,117 \text { adolescents } \\
\text { ( } 449 \text { boys, } 668 \text { girls) } \\
\text { aged } 15, \\
\text { regional sample } \\
\text { the Czech Republic } \\
729 \text { adolescents } \\
\text { ( } 296 \text { boys, } 433 \text { girls) } \\
\text { aged } 15, \\
\text { regional sample } \\
\text { Poland }\end{array}$ & $\begin{array}{l}\text { IPAQ (long form), } \\
\text { last } 7 \text { days }\end{array}$ & $\begin{array}{l}\text { VPA (at least } 20 \text { minutes on } 3 \\
\text { or more days per week) } \\
\text { MVPA (at least } 60 \text { minutes } \\
\text { every day) }\end{array}$ & $\begin{array}{l}\text { Czech Republic } \\
\text { VPA: } 45.9 \% \text { boys, } 33.4 \% \text { girls } \\
\text { MVPA: } 32.3 \% \text { boys, } 20.1 \% \text { girls } \\
\text { Poland } \\
\text { VPA: } 64.5 \% \text { boys, } 51.3 \% \text { girls } \\
\text { MVPA: } 40.5 \% \text { boys, } 25.2 \% \text { girls }\end{array}$ \\
\hline Gába et al. [26] & $\begin{array}{l}365 \text { children } \\
\text { (156 boys, } 209 \text { girls) } \\
\text { aged } 7-12, \\
\text { regional representative sample } \\
\text { the Czech Republic }\end{array}$ & $\begin{array}{l}\text { Accelerometer ActiGraph (ActiGraph, LLC., } \\
\text { FL, USA), number of days physically active } \\
\text { at least } 60 \text { minutes for } \\
\text { at least } 4 \text { days including } 1 \text { weekend day }\end{array}$ & $\begin{array}{l}\text { At least } 60 \text { minutes per day } \\
\text { of MVPA }\end{array}$ & $22.0 \%$ boys, $8.0 \%$ girls \\
\hline $\begin{array}{l}\text { Kalman et al. } \\
{[27]}\end{array}$ & $\begin{array}{l}\text { 4,385 children } \\
(2,126 \text { boys, } 2,259 \text { girls }) \\
\text { aged } 11,13,15, \\
\text { national representative sample } \\
\text { Czech Republic }\end{array}$ & $\begin{array}{l}\text { HBSC study: self-reported MVPA, number } \\
\text { of days physically active at least } 60 \\
\text { minutes, last } 7 \text { days }\end{array}$ & $\begin{array}{l}\text { At least } 60 \text { minutes per day } \\
\text { of MVPA }\end{array}$ & $\begin{array}{l}\text { aged } 11: 28.0 \% \text { boys, } 23.3 \% \text { girls } \\
\text { aged } 13: 29.5 \% \text { boys, } 19.0 \% \text { girls } \\
\text { aged } 15: 24.8 \% \text { boys, } 14.3 \% \text { girls }\end{array}$ \\
\hline $\begin{array}{l}\text { Kantanista et al. } \\
\text { [28] }\end{array}$ & $\begin{array}{l}175 \text { girls } \\
\text { aged } 12-13,15-16,17-18, \\
\text { regional sample } \\
\text { Poland }\end{array}$ & $\begin{array}{l}\text { Yamax Digi-Walker SW } 701 \text { pedometer, } \\
\text { step counts, } 7 \text { consecutive days }\end{array}$ & 12,000 steps per day & $\begin{array}{l}\text { aged } 12-13: 15.6 \% \text { girls } \\
\text { aged } 15-16: 11.6 \% \text { girls } \\
\text { aged } 17-18: 18.0 \% \text { girls }\end{array}$ \\
\hline Kokko et al. [29] & $\begin{array}{l}10,426 \text { children and } \\
\text { adolescents } \\
\text { aged } 11,13,15, \\
\text { national representative sample } \\
\text { Czech Republic }\end{array}$ & $\begin{array}{l}\text { HBSC study: self-reported MVPA, number } \\
\text { of days physically active at least } 60 \\
\text { minutes, last } 7 \text { days }\end{array}$ & $\begin{array}{l}\text { At least } 60 \text { minutes per day } \\
\text { of MVPA }\end{array}$ & $\begin{array}{l}\text { overall: } 21.0 \% \\
\text { aged } 11: 26.0 \% \\
\text { aged } 13: 21.0 \% \\
\text { aged } 15: 17.0 \% \\
24.0 \% \text { boys, } 18.0 \% \text { girls }\end{array}$ \\
\hline $\begin{array}{l}\text { McMahon et al. } \\
{[30]}\end{array}$ & $\begin{array}{l}975 \text { adolescents } \\
\text { ( } 416 \text { boys, } 559 \text { girls) } \\
\text { aged } 15, \text { national } \\
\text { representative sample } \\
\text { Hungary }\end{array}$ & $\begin{array}{l}\text { Modified version of the PACE + (Patient- } \\
\text { Centred Assessment and Counselling for } \\
\text { Exercise Plus Nutrition), number of days } \\
\text { physically active at least } 60 \text { minutes, last } \\
2 \text { weeks }\end{array}$ & $\begin{array}{l}\text { At least } 60 \text { minutes per day } \\
\text { of MVPA }\end{array}$ & $14.6 \%$ boys, $8.5 \%$ girls \\
\hline $\begin{array}{l}\text { Schwarzfischeret } \\
\text { al. [31] }\end{array}$ & $\begin{array}{l}62 \text { children } \\
\text { aged } 11, \\
\text { regional sample } \\
\text { Poland }\end{array}$ & $\begin{array}{l}\text { SenseWear Armband } 2 \text { (SWA), Part of the } \\
\text { European CHOP trial (Childhood Obesity } \\
\text { Project), } \\
\text { at least } 3 \text { consecutive days }\end{array}$ & $\begin{array}{l}\text { At least } 60 \text { minutes per day } \\
\text { of MVPA }\end{array}$ & $69.4 \%$ overall \\
\hline $\begin{array}{l}\text { Sigmund et al. } \\
{[12]}\end{array}$ & $\begin{array}{l}\text { 5,750 children and adolescents } \\
\text { (2,803 boys, } 2,947 \text { girls) } \\
\text { aged } 10.5-16.5 \\
\text { national representative sample } \\
\text { Czech Republic }\end{array}$ & $\begin{array}{l}\text { HBSC study: self-reported MVPA and VPA, } \\
\text { last } 7 \text { days }\end{array}$ & $\begin{array}{l}\text { At least } 60 \text { minutes of MVPA } \\
\text { per day, } \\
\text { At least } 30 \text { minutes and at } \\
\text { least } 4 \text { days per week VPA }\end{array}$ & $\begin{array}{l}\text { MVPA } \\
\text { overall: } 25.6 \% \text { boys, } 19.2 \% \text { girls } \\
\text { aged } 10.5-12.49: 29.5 \% \text { boys, } 24.2 \% \text { girls } \\
\text { aged } 12.5-14.49: 27.2 \% \text { boys, } 20.1 \% \text { girls } \\
\text { aged } 14.5-16.49: 20.4 \% \text { boys, } 13.6 \% \text { girls } \\
\text { VPA } \\
\text { overall: } 42.0 \% \text { boys, } 33.6 \% \text { girls } \\
\text { aged } 10.5-12.49: 39.4 \% \text { boys, } 34.4 \% \text { girls } \\
\text { aged } 12.5-14.49: 42.6 \% \text { boys, } 36.2 \% \text { girls } \\
\text { aged } 14.5-16.49: 44.4 \% \text { boys, } 30.2 \% \text { girls }\end{array}$ \\
\hline $\begin{array}{l}\text { Sigmundová } \\
\text { et al. [32] }\end{array}$ & $\begin{array}{l}194 \text { children } \\
\text { (106 boys, } 88 \text { girls) } \\
\text { aged } 5 \text {, } \\
\text { regional representative sample } \\
\text { Czech Republic }\end{array}$ & $\begin{array}{l}\text { Yamax Digiwalker SW- } 200 \text { pedometer, } \\
\text { step counts, } \\
7 \text { consecutive days (at least } 4 \text { weekdays } \\
\text { and } 2 \text { weekend days) }\end{array}$ & 11,500 steps per day & $\begin{array}{l}\text { Weekdays: } 50.5 \% \text { boys, } 48.3 \% \text { girls } \\
\text { Weekends: } 53.3 \% \text { boys, } 39.8 \% \text { girls }\end{array}$ \\
\hline Tabak et al. [33] & $\begin{array}{l}1,287 \text { adolescents } \\
\text { ( } 579 \text { boys, } 708 \text { girls) } \\
\text { aged } 14-18, \\
\text { national representative sample } \\
\text { Poland }\end{array}$ & $\begin{array}{l}\text { HBSC study: self-reported MVPA, number } \\
\text { of days physically active at least } 60 \\
\text { minutes, } \\
\text { last } 7 \text { days }\end{array}$ & $\begin{array}{l}\text { At least } 60 \text { minutes per day } \\
\text { of MVPA }\end{array}$ & $22.8 \%$ boys, $7.5 \%$ girls \\
\hline
\end{tabular}


This was confirmed by Balaban [39], who showed that among Czech children aged 8-11 years there was a low-to-medium correlation between MVPA and locomotor skills.

Regarding demographic data - the number of citizens in the Visegrád countries aged 0-14 and 15-18 [40] - the largest research sample consisting of children and adolescents was analysed in the Czech Republic. Exploring this topic was important because Czech results can form a valuable part of the argument concerning the physical activity of children and adolescents from the Visegrád countries, in addition to motivating researchers from Poland, Slovakia, and Hungary. The results of this study confirmed that there was no clear country-based pattern to meeting physical activity recommendations and percentages differed (by several points) depending on the research methodology and population size. However, the ranges followed global trends showing that only about $20 \%$ of adolescents meet physical activity recommendations, and that the prevalence of sufficient activity is higher among boys in comparison to girls [7].

This review found that the recommended levels of physical activity differed depending on the country of origin of the children and adolescents. The recommended MVPA level was achieved by $69.4 \%$ of the examined 11 -year-old children from Poland [31]. This result is 48.4 points higher than the statistic for Czech children and adolescents [29] and 44.3 points higher than adolescents from Slovakia [24]. These findings are fundamentally different from those of Guthold et al. [7], which may be a result of the selection of the research sample [31]. Generally, the largest percentage of children and adolescents meeting the recommended MVPA was found in Slovakia, followed by Poland and then the Czech Republic [16]; the lowest percentage was observed in children and adolescents from Hungary. It should be noted that young people have the opportunity to take additional hours of physical activity classes in Slovakian and Czech schools [16]; therefore it seems that physical activity undertaken voluntarily can increase the overall level physical activity of children and adolescents.

Whether physical activity was measured using objective or subjective methods may have had a consequence on the results obtained. Subjective measures include physical activity diaries, observation, and recall questionnaires, and are considered practical, low cost, and easy to use [41]. However, subjective measures present limitations in poorer reliability and validity, participant recall bias, and interpretation of questions [42]. In physical activity assessment, objective methods include measures that directly assess frequency, intensity, time and type. The number of steps, minutes of activity, intensity of activity, and bouts of activity can be measured [43]. Commonly used tools include accelerometers, pedometers, and heart rate monitors, as well as indirect calorimetry and direct observation.

In the studies analysed, electronic tools were used five times (two different accelerometers and three different pedometers). Physical activity monitors do not accurately assess movements that require extra effort, such as walking uphill or carrying loads. In the case of accelerometers, accuracy measures were greatest when detecting sedentary behaviour and lowest when detecting light physical activity. Accuracy is generally higher when the accelerometer is placed on the hip compared to the wrist [44]. Pedometers allow evaluation of the number of steps but not the intensity of physical activity [45]. Also, the SenseWear Armband used in the study of Schwarzfisher et al. [31] could be a useful tool for determining levels of energy expenditure at low intensities rather than high intensities [46]. Self-reported measures were used seven times and all included in the review studies were cross-sectional.

The limitations of the results obtained in this review arise from different researchers using different types of measurement methods (objective and subjective), different sample sizes and different guidelines or recommendations. This makes it impossible to reliably compare the prevalence of physical activity in different countries. As this review was restricted to published studies in English using selected databases, publication bias may be present.

\section{CONCLUSIONS}

Despite recommendations for physical activity by international and local bodies, physical inactivity is an increasing global health burden. In the Visegrád countries, a large proportion of children and adolescents did not meet the physical activity recommendations. National and local authorities and schools in the Visegrád countries should implement strategies to increase the level of physical activity, especially in girls. Compared to boys, fewer girls met physical activity recommendations.

This review highlights the need for further studies with representative random samples that use validated measurement methods to eliminate significant discrepancies in the results and ultimately obtain reliable data on the levels of physical activity of children and adolescents. In the studies, VPA should be measured more often because according to literature VPA may be more beneficial for health outcomes than MVPA.

\section{Acknowledgments}

The authors would like to thank Justyna Andrzejczak, who assisted with the electronic searches of computerised databases.

\section{REFERENCES}

1. Physical Activity Guidelines Advisory Committee Scientific Report Washington, DC: US Department of Health and Human Services, 2018.

2. Janssen I. Physical activity guidelines for children and youth. Appl Physiol Nutr Metab. 2007; 32: 109-121. https://doi.org/10.1139/H07-109

3. Janssen I, Leblanc A. Systematic review of the health benefits of physical activity and fitness in school-aged children and youth. Int J Behav Nutr Phys Act. 2010; 7: 40. https://doi.org/10.1186/1479-5868-7-40

4. Centers for Disease Control and Prevention. The association between school-based physical activity, including physical education, and academic performance. Atlanta, GA; Centers for Disease Control and Prevention, US Department of Health and Human Services, 2010.

5. Kantanista A, Osiński W. Underweight in 14 to 16 year-old girls and boys: prevalence and associations with physical activity and sedentary activities. Ann Agric Environ Med. 2014; 21(1): 114-119.

6. World Health Organization. Global recommendations on physical activity for health. Geneva, Switzerland: WHO, 2010.

7. Guthold R, Stevens GA, Riley LM, Bull FC. Global trends in insufficient physical activity among adolescents: a pooled analysis of 298 population-based surveys with 1.6 million participants. Lancet Child Adolesc Health. 2020; 4(1): 23-35. https://doi.org/10.1016/S23524642(19)30323-2

8. Inchley J, Currie D, Young T, Samdal O, Torsheim T, Augustson L et al. (Eds.). (2016). Growing up unequal: Gender and socioeconomic differences in young people's health and well-being. Health behaviour 
in school-aged children (HBSC) study: International report from the 2013/2014 survey. (Health Policy for Children and Adolescents, No. 7). Copenhagen: WHO Regional Office for Europe. WHO, 2016.

9. Parikh T, Stratton G. Influence of intensity of physical activity on adiposity and cardiorespiratory fitness in 5-18 year olds. Sports Med. 2011; 41: 477-488. https://doi.org/10.2165/11588750-000000000-00000

10. Owens S, Galloway R, Gutin B. The case for vigorous physical activity in youth. Am J Lifestyle Med. 2017; 11(2): 96-115. https://doi. org/10.1177/1559827615594585

11. Frömel K, Groffik D, Chmelík F, Cocca A, Skalik K. Physical activity of 15-17 years old adolescents in different educational settings: a PolishCzech study. Cent Eur J Publ Heal. 2018; 26(2): 137-143. https://doi. org/10.21101/cejph.a4521

12. Sigmund E, Sigmundová D, Badura P, Kalman M, Hamrik Z, Pavelka, J. Temporal trends in overweight and obesity, physical activity and screen time among Czech adolescents from 2002 to 2014: A national health behaviour in school-aged children study. Int J Environ Res Public Health. 2015; 12(9): 11848-11868. https://doi.org/10.3390/ ijerph120911848

13. World Health Organization. Childhood Obesity Surveillance Initiative (COSI) Factsheet. Highlights 2015-17. WHO, 2018.

14. Global health risks: mortality and burden of disease attributable to selected major risks. Geneva, WHO, 2009.

15. Niźnikowska E, Bergier J, Bergier B, Ăcs P, Junger J, Salonna F. Factors influencing levels of physical activity among female students from the Visegrad countries. Health Probl Civilz. 2019; 13(1): 19-29. https://doi. org/10.5114/hpc.2018.80225

16. World Health Organization. Physical activity factsheets for the 28 European Union member states of the WHO European Region. WHO, 2018.

17. Lubowiecki-Vikuk A, Biernat E. Organized and unorganized forms of leisure time physical activity among junior high school students in relation to individual and socio-environmental factors. Probl Hig Epidemiol. 2015; 96(2): 448-457.

18. Sterdt E, Liersch S, Walter U. Correlates of physical activity of children and adolescents: A systematic review of reviews. Health Educ J. 2014; 73(1): 72-89. https://doi.org/10.1177/0017896912469578

19. Bakalar P, Kopcakova J, Geckova AM. Association between potential parental and peers'correlates and physical activity recommendations compliance among 13-16 years old adolescents. Acta Gymnica. 2019; 49(1): 16-24. https://doi.org/10.5507/ag.2018.027

20. Adamo KB, Prince SA, Tricco AC, Connor-Gorber S, Tremblay M. A comparison of indirect versus direct measures for assessing physical activity in the pediatric population: A systematic review. Int J Pediatr Obes. 2009; 4(1): 2-27. https://doi.org/10.1080/17477160802315010

21. Bergier J. A critical review of physical activity figures for comparison studies using IPAQ surveys and accelerometer measurements. J Health Inequal. 2017; 3(1): 78-82. https://doi.org/10.5114/jhi.2017.69171

22. Marker AM, Steele RG, Noser AE. Physical activity and health-related quality of life in children and adolescents: A systematic review and meta-analysis. Health Psychol. 2018; 37(10): 893-903. https://doi. org/10.1037/hea0000653

23. Liberati A, Altman D, Tetzlaff J, Mulrow C, Gøtzsche PC, Ioannidis JP, et al. The PRISMA statement for reporting systematic reviews and meta-analyses of studies that evaluate health care interventions: Explanation and elaboration. PLoS Med. 2016; 6: e1000100. https://doi. org/10.1371/journal.pmed.1000100

24. Brindova D, Veselska ZD, Klein D, Hamrik Z, Sigmundova D, van Dijk JP, Geckova AM. Is the association between screen-based behaviour and health complaints among adolescents moderated by physical activity? Int J Public Health. 2015; 60(2): 139-145. https://doi.org/10.1007/ s00038-014-0627-x

25. Czajka K, Sławińska T, Kołodziej M, Kochan, K. Assessment of physical activity by pedometer in Polish preschool children. Hum Mov. 2015; 16(1): 15-19. https://doi.org/10.1515/humo-2015-0021

26. Gába A, Mitáš J, Jakubec L. Associations between accelerometermeasured physical activity and body fatness in school-aged children. Environ Health Prev Med. 2017; 22(1): 43. https://doi.org/10.1186/ s12199-017-0629-4

27. Kalman M, Hamrik Z, Sigmund E, Sigmundová D, Salonna F. Physical activity of Czech adolescents: Findings from the HBSC 2010 study. Acta Gymnica. 2015; 45(1): 3-11. https://doi.org/10.5507/ag.2015.001
28. Kantanista A, Król-Zielińska M, Borowiec J, Glapa A, Lisowski P, Bronikowski M. Physical activity of female children and adolescents based on step counts: meeting the recommendation and relation to BMI. Biomed Hum Kinet. 2015; 7(1): 66-72. https://doi.org/10.1515/ bhk-2015-0011

29. Kokko S, Martin L, Geidne S, Van Hoye A, Lane A, Meganck J, Badura P. Does sports club participation contribute to physical activity among children and adolescents? A comparison across six European countries. Scand J Public Health. 2018; 47(8): 851-858. https://doi. org/10.1177/1403494818786110

30. McMahon E, Corcoran P, O’Regan G, Keeley H, Cannon M, Carli V, et al. Physical activity in European adolescents and associations with anxiety, depression and well-being. Eur Child Adolesc Psychiatry. 2017; 26(1): 111-122. https://doi.org/10.1007/s00787-016-0875-9

31. Schwarzfischer P, Weber M, Gruszfeld D, Socha P, Luque V, Escribano $\mathrm{J}$, et al. BMI and recommended levels of physical activity in school children. BMC Public Health. 2017; 17(1): 595. https://doi.org/10.1186/ s12889-017-4492-4

32. Sigmundová D, Sigmund E, Badura P, Vokáčová J, Trhlíková L, Bucksch J. Weekday-weekend patterns of physical activity and screen time in parents and their pre-schoolers. BMC Public Health. 2016; 16(1): 898. https://doi.org/10.1186/s12889-016-3586-8

33. Tabak I, Mazur J, Nałęcz H. Family and individual predictors and mediators of adolescent physical activity. Health Psychol Rep. 2017; 5(4): 333-344. https://doi.org/10.5114/hpr.2017.67522

34. Ács P, Bergier J, Salonna F, Junger J, Melczer C, Makai A. Gender differences in physical activity among secondary school students in the Visegrad countries (V4). Health Probl Civiliz. 2016; 10(3): 21-29. https://doi.org/10.5114/hpc.2016.61363

35. Bergier B, Bergier J, Paprzycki P. Level and determinants of physical activity among school adolescents in Poland. Ann Agric Environ Med. 2014; 21(1): 75-78.

36. Kantanista A, Osiński W. Physical activity of Poles-Critical analysis of research 2010-2014. Ann Agric Environ Med. 2014; 21(4): 839-843. https://doi.org/10.5604/12321966.1129944

37. Carson V, Spence JC. Seasonal variation in physical activity among children and adolescents: A review. Pediatr Exerc Sci. 2010; 22(1): 81-92. https://doi.org/10.1123/pes.22.1.81

38. Osiński W. Socio-economic differences in body build and motor ability of children and adolescents. Stud Phys Cult Tour. 1994; 3: 25-35.

39. Balaban V. The relationship between objectively measured physical activity and fundamental motor skills in 8 to 11 years old children from the Czech Republic. Monten J Sports Sci Med. 2018; 7(2): 11-16. https://doi.org/10.26773/mjssm.180902

40. EUROSTAT. Being young in Europe today. Publications Office of the European Union, 2015.

41. Ainsworth B, Cahalin L, Buman M, Ross R. The current state of physical activity assessment tools. Prog Cardiovasc Dis. 2015; 57 (4): 387-395. https://doi.org/10.1016/j.pcad.2014.10.005

42. Welk GJ. Physical activity assessments for health-related research. Champaign, IL: Human Kinetics, 2002.

43. Strath SJ, Kaminsky LA, Ainsworth BE, Ekelund U, Freedson PS, Gary RA, et al. Guide to the assessment of physical activity: clinical and research applications: a scientific statement from the American Heart association. Circulation. 2013; 128(20): 2259-2279. https://doi. org/10.1161/01.cir.0000435708.67487.da

44. Lynch BA, Kaufman TK, Rajjo TI, Mohammed K, Kumar S, Murad MH, et al. Accuracy of accelerometers for measuring physical activity and levels of sedentary behavior in children: A Systematic Review. J Prim Care Community Health. 2019; 10. https://doi.org/10.1177/2150132719874252

45. Kantanista A, Bronikowski M, Laudańska-Krzemińska I, Król-Zielińska M, Osiński W. Positive effect of pedometer-based walking intervention on body image and physical activity enjoyment in adolescent girls. Biomed Hum Kinet. 2017; 9(1): 34-42. https://doi.org/10.1515/bhk2017-0006

46. Santos-Lozano A, Hernández-Vicente A, Pérez-Isaac R, SantínMedeiros F, Cristi-Montero C, Casajús JA, et al. Is the SenseWear Armband accurate enough to quantify and estimate energy expenditure in healthy adults? Ann Transl Med. 2017; 5(5): 97. https://doi. org/10.21037/atm.2017.02.31 